\title{
螺旋羽を持つ回転貫入杭の貫入および支持力に関する基礎的研究 FUNDAMENTAL STUDY ON PENETRATION AND BEARING CAPACITY OF SCREW PILE WITH HELICAL WING
}

\author{
国府田 誠*1，佐 藤 秀人*2，刑 部 徹*3，国 司 基*4 \\ 永田誠*5, 平田 尚*5, 田村昌仁*6 \\ Makoto KOUDA, Hideto SATO, Toru OSAKABE, Hajime KUNISHI, \\ Makoto NAGATA, Hisashi HIRATA and Masahito TAMURA
}

\begin{abstract}
In this paper, model experiment for screw pile with single helical wing is described. The experiment was performed in order to discuss behavior of the bearing capacity of the wing the pile tip and the pile surface friction in penetration stage and in vertical loading stage. Particularly, in the penetration stage, the wing works as a device, which drives the pile body and facilitates the penetration by reducing restrain pressure in the pile tip area. In the vertical loading stage, the wing works as a part of bearing device and contributes to increase of the pile tip bearing capacity by increment of the restrain pressure in the pile tip area.
\end{abstract}

Keywords: Screw Pile, Model Experiment, Penetration Test, Bearing Capacity

回転貫入杭，模型試験，貫入機構，支持力特性

\section{1. 序 論}

\section{(1) 研究の背景}

杭軸を回転させる貫入杭は, 杭頭圧入力を軽减させるために回転 させるもの (回転圧入杭と呼ぶ)，主に杭先端あるいは杭周に取り付 けたスクリューなどの回転推進力によって貫入させるもの（回転貫 入杭と呼ぶ）に大別される。いずれも無振動・無騒音であり，無排 土貫入が可能である。特に，羽推進力を主とする回転貫入杭は，逆 回転によって撤去が容易に行えるため，建物の基礎地盤としての再 生が容易に行えること，資源としての再利用が可能なことなど，環 境問題においても優れている。また, 羽部が应底機能を有すること， 無排土施工杭（Displacement Pile）であることなど，支持力的にも期 待されている。

回転貫入杭の歷史は, 既に 1838 年においてその存在が記述されて いる ${ }^{1)}$ 。日本では 1985 年頃から戸建住宅などの小規模建物の基礎と して，小径（100〜150mm 程度）のものが開発され ${ }^{2)}$, 載荷試験に よる支持力や杭体強度についての研究が行われるようになった。現 在では施工例も增え，大型建築物を対象とした軸径 $1600 \mathrm{~mm}$ （最大
羽径 $2400 \mathrm{~mm}$ ）におよぶものも開発されている。回転貫入杭は，打 撃杭や圧入杭と同じ無排土施工杭に属しているが，杭先端の形状や 杭体の埋設方法において, 根本的な違いがあり, 支持力性状も大き く異なるものと思われる。しかし，その設計や施工は，貫入試験や 載荷試験に基づいて行われているのが現状であり，より適切な設計 法と施工法の確立が必要と思われる。

(2) 研究の経緯

筆者 ${ }^{3 \vdash \sim 10)}$ は, 杭体の各部位（杭頭, 杭周面, 羽, 杭先端部) の荷重が測定可能な模型杭を製作し，貫入試験，載荷試験および崩 壊地盤の可視化試験を行い, 本論文の基本となるところを形成した。

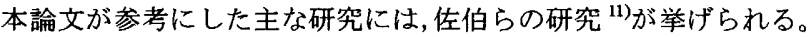
特に, 杭先端部の釣合式や回転貫入および支持力の力学的モデルは, 教えられるところが多くあった。その他には，土屋らの大型実験装 置による杭施工法(回転貫入)に関する研究 ${ }^{12)}$ １4)がある。特に，杭 施工管理としての杭体トルク，施工後の残留軸力分布，羽近傍の力 学的挙動など，本論文の作成に参考となるところが多くあった。
*1 日本大学理工学部海洋建築工学科 教授. 工博

*2 日本大学理工学部海洋建築工学科 専任講師·工博

*3 日本大学大学院理工学研究科 研究員

*4 日本大学大学院理工学研究科 博士前期課程

*5 新日本製鐵(侏建築事業部

*6 建築研究所 上席研究員 · 工博
Prof., Dept. of Oceanic Architecture \& Eng., Nihon Univ., Dr. Eng. Assist. Prof., Dept. of Oceanic Architecture \& Eng., Nihon Univ., Ph. D. Researcher, Graduate School of Science \& Tech., Nihon Univ., Ph. D. Graduate Student, Graduate School of Science \& Tech., Nihon Univ. Building Construction Div., Nippon Steel Co. Chief Research Engineer, Building Research Institute, Dr. Eng. 


\section{(3) 研究の目的}

本研究は，回転貫入杭が持つ特有の貫入メカニズムや支持力発現 のメカニズムの解明と貫入および支持力の各力学モデルの構築に向 けて，杭体各部位の荷重〜沈下関係などの基礎的性状とその原理の 把握を目的とする。

\section{2. 実験概要}

\section{(1) 試験の種類}

表 1 に試験の種類を示す。試験 1 ～5は，羽ピッチをパラメータ としたもの，試験 6 は，回転貫入杭と軸径を同じくするストレート 杭であり，回転貫入杭の試験結果の比較基準とするものである。

\section{（2）模型杭と荷重計}

模型杭は, 図 1 に示寸ように杭の胴体部, 長さ $65 \mathrm{~mm}$ の先端部 (写 真 1) および胴体部と同一径の厚さ $5 \mathrm{~mm}$ の軸部先端で構成してい る。図 2 に示すように, 杭体に内藏した軸力計およびトルク計より， 杭頭鉛直荷重 $\mathrm{P}_{0}$ ，杭頭トルク $\mathrm{T}_{0}$ ，胴体部と先端部の接合部にお ける軸力（先端部鉛直摩擦力 $\Delta \mathrm{Q}_{\mathrm{rV}}+$ 軸部先端荷重 $\mathrm{R}_{\mathrm{P}}$ ) とトルク（先 端部トルク $\mathrm{T}_{\mathrm{w}}+$ 先端部周面トルク $\Delta \mathrm{T}_{\mathrm{f}}+$ 軸部先端トルク $\mathrm{T}_{\mathrm{p}}$ ) およ び軸部先端荷重 $R_{p}$ を直接的に測定する。なお，杭胴体部に作用する 鈆直摩擦荷重 $\mathrm{Q}_{\mathrm{fv}}{ }^{*}$ は $\mathrm{P}_{0}$ と上記接合部軸力の差として求め, 胴体部の 摩摖トルク $\mathrm{T}_{\mathrm{f}}^{*}$ は $\mathrm{T}_{0}$ と接合部トルクの差として算出する。

表 1 試験の諸元

\begin{tabular}{|c|c|c|c|c|c|c|}
\hline 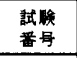 & 杭理 & 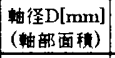 & $\begin{array}{c}\text { 羽径 } \mathrm{D}_{\boldsymbol{w}}[\mathrm{mm}] \\
\text { (羽部面 }\end{array}$ & \begin{tabular}{|l} 
羽厚 \\
[mm]
\end{tabular} & $\begin{array}{l}\text { 羽ピッ千 } \\
\text { hulmml } \\
\end{array}$ & $\begin{array}{l}\text { 埋設 } \\
\text { 方法 }\end{array}$ \\
\hline 1 (P8) & \multirow{5}{*}{ 回轱鿓入杭 } & \multirow{6}{*}{$\begin{array}{c}48 \\
\left(1810 \mathrm{~mm}^{2}\right)\end{array}$} & \multirow{5}{*}{$\begin{array}{c}86 \\
\left(3999 \mathrm{~mm}^{2}\right)\end{array}$} & \multirow{5}{*}{4} & 8 & \multirow{5}{*}{ 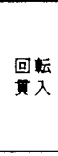 } \\
\hline 2 (P12) & & & & & 12 & \\
\hline 3 (P16) & & & & & 16 & \\
\hline $4(\mathrm{P} 24)$ & & & & & 24 & \\
\hline 5 (P36) & & & & & 36 & \\
\hline 6 & ストレート杭 & & - & - & - & $\begin{array}{l}\text { 無回蚣 } \\
\text { 压入 }\end{array}$ \\
\hline
\end{tabular}

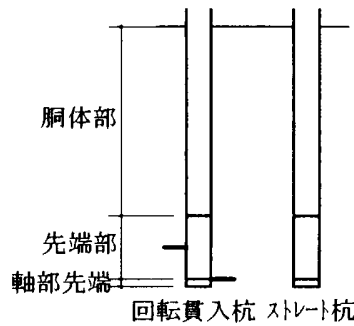

図 1 杭体の部位

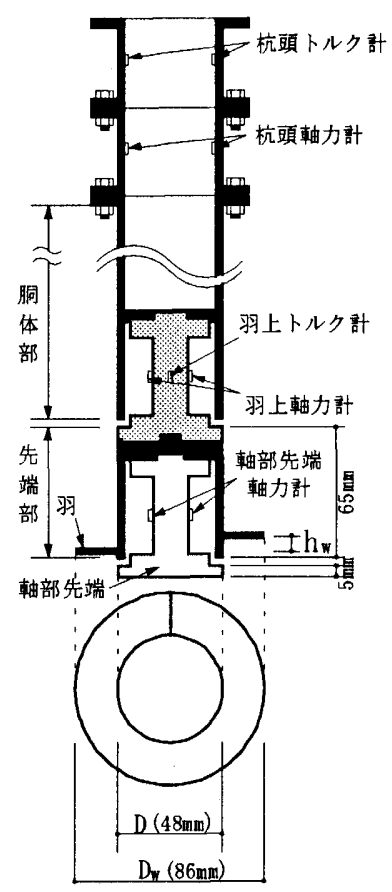

図 2 模型杭詳細図

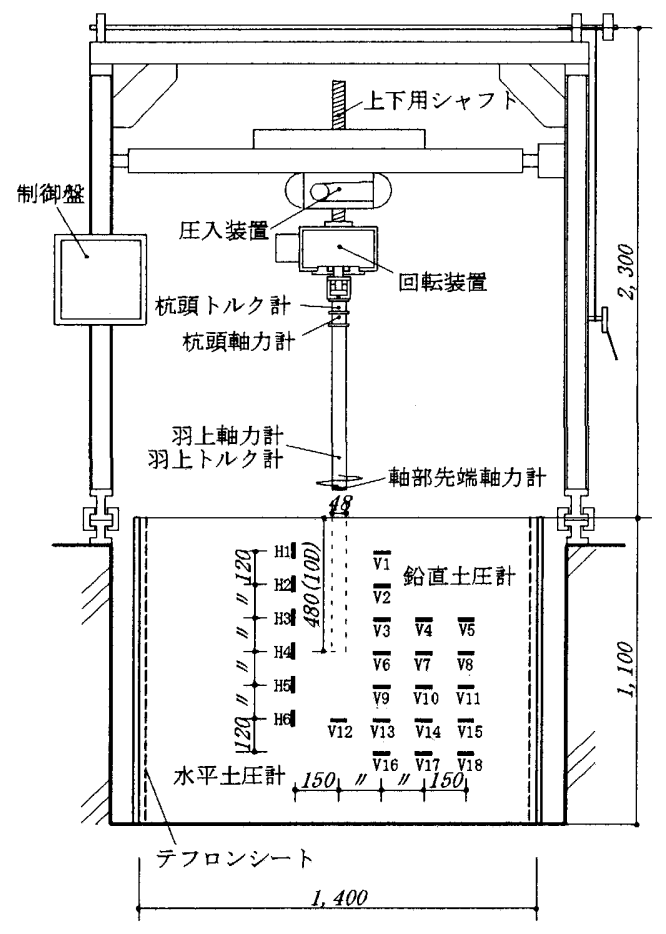

図 3 試験装置
（3）模型地盤と土圧の測定

模型地盤は図 3 に示すような円筒形土槽を用い，その内壁には， テフロンシートを貼付し，槽壁の影響を極力排除した。模型地盤は 気乾状態の珪砂 5 号を使用した。その諸元を表 2 に示寸。なお，標 準貫入試駼機により，地表面から連続打撃し， $30 \mathrm{~cm}$ を一打撃当たり の貫入量で除した值を換算 $\mathrm{N}$ 值として図 4 に示した。図 3 に示した ように，24 個のひずみゲージ式土圧計（径 $50 \mathrm{~mm}$ ，厚さ $11 \mathrm{~mm}$ ）を， 水平土圧用 6 個，鉛直土圧用 18 個を模型地盤中に埋設し，貫入時お よび載荷時の土圧変動量を測定した。

（4）貫入方法および載荷方法

貫入試験は，軸径（D=48mm）の 10 倍（480mm）を貫入し，載荷 試験は, 貫入試験に引き続き, 杭頭変位 $48 \mathrm{~mm}$ (1D) まで載荷する。 その装置を図 3 に示す。回転貫入試験は変位制御方式によるもので あり，回転速度を一定に保ち $(0.5 \mathrm{rpm})$, 鉛直荷重 $\mathrm{P}_{0}=0$ を極力維 持するように制御した。載荷試験は，貫入試験の終了後，余分な回 転や荷重を与えないように杭頭を固定した状態で，約 1 分間を置い て，1 $\mathrm{mm} / \mathrm{min}$ 変位速度で実施した。したがって，杭頭の回転が拘束 された状態の載荷試験となる。なお，載荷試験は杭頭の回転が開放 した状態から始めるのが好ましいと思われるが，長い杭などは杭体 表面の摩擦抵抗トルクよって回転が拘束される場合もあることや， 支持力性状の把握に大きな問題が無いものと判断し，杭頭の回転を 拘束した状態で実施した。なお，試験 6 のスとレート杭については， 
$5 \mathrm{~mm} / \mathrm{min}$ の速度で無回転圧入を行い, 杭頭荷重 $\mathrm{P}_{0}$ を除荷した後に 載荷試験を実施した。

(5) 計 測

軸力計とトルク計, 模型地盤中に埋設した土圧計の計測は，全て 貫入試験直前を原点とし，貫入試験および載荷試験を通して，それ らの增减値を測定した。

\section{3. 貫入試験結果と貫入のメカニズム}

(1) 回転貫入のメカニズム

\section{(1) 基礎事項}

本回転貫入のメカニズムの説明は，以下の仮定に従う。

基本仮定 1 : 羽厚の影響を無視し, 羽刃先および羽厚周面部の応 力を無視する。

基本仮定 2 : 回転貫入時の先端地盤は破壊状態, 羽部および杭周 面はすべり状態にある。

図 5 に，杭体の各部位の荷重を示す。ただし，同 $\mathrm{a}$ は, 鈶直方向 荷重を示し, $\mathrm{P}_{0}$ は杭頭, $\mathrm{P}_{\mathrm{w} 1}$ は羽上面, $\mathrm{P}_{\mathrm{w} 2}$ は羽下面, $\mathrm{Q}_{\mathrm{fv}}$ は杭周 面， $R_{\mathrm{p}}$ は軸部先端面の各鉛直荷重である。同図 $\mathrm{b}$ はトルクを示し， $\mathrm{T}_{0}$ は杭頭, $\mathrm{T}_{\mathrm{f}}$ は杭周面, $\mathrm{T}_{\mathrm{w} 1}$ は羽上面, $\mathrm{T}_{\mathrm{w}_{2}}$ は羽下面, $\mathrm{T}_{\mathrm{p}}$ は軸 部先端面のトルクである。同図 $\mathrm{c}$ は, 杭周部を平面展開した図上に 示した荷重であり， $Q_{0}, Q_{\mathrm{fH}}, \mathrm{Q}_{\mathrm{w1}}$ および $\mathrm{Q}_{\mathrm{w} 2}$ の各荷重は， $\mathrm{T}_{0}, \mathrm{~T}$ $\mathrm{f}, \mathrm{T}_{\mathrm{wl}}, \mathrm{T}_{\mathrm{w} 2}$ の換算水平力, $\mathrm{Q}_{\mathrm{f}}$ は杭周面摩擦力の鉛直成分 $\mathrm{Q}_{\mathrm{fv}}$ と換 算水平摩擦力 $\mathrm{Q}_{\mathrm{H}}$ の合力である。また， $\theta_{\mathrm{w}}$ は杭胴体面における蝶旋 羽の角度である。図 5 の各荷重の符号は図示の方向を正とし，これ らの釣合式は以下の通りである。

$$
\begin{array}{ll}
\mathrm{P}_{0}=\mathrm{Q}_{\mathrm{fv}}+\mathrm{R}_{\mathrm{p}}+\mathrm{P}_{\mathrm{w}}, \mathrm{P}_{\mathrm{w}}=\mathrm{P}_{\mathrm{w} 2}-\mathrm{P}_{\mathrm{w} 1} & (1-\mathrm{a}) \\
\mathrm{T}_{0}=\mathrm{T}_{\mathrm{f}}+\mathrm{T}_{\mathrm{p}}+\mathrm{T}_{\mathrm{w}}, \mathrm{T}_{\mathrm{w}}=\mathrm{T}_{\mathrm{w} 2}+\mathrm{T}_{\mathrm{wl}} & (1-\mathrm{b}) \\
\mathrm{Q}_{0}=\mathrm{Q}_{\mathrm{fH}}+\mathrm{Q}_{\mathrm{p}}+\mathrm{Q}_{\mathrm{w}}, \mathrm{Q}_{\mathrm{w}}=\mathrm{Q}_{\mathrm{w} 2}+\mathrm{Q}_{\mathrm{w} 1} & (1-\mathrm{c}) \\
こ こ に, & \mathrm{Q}_{0}=2 \mathrm{~T}_{0} / \mathrm{D}, \mathrm{Q}_{\mathrm{fH}}=2 \mathrm{~T}_{\mathrm{f}} / \mathrm{D}, \mathrm{Q}_{\mathrm{w} 1}=2 \mathrm{~T}_{\mathrm{w} 1} / \mathrm{D}, \\
\mathrm{Q}_{\mathrm{w} 2}=2 \mathrm{~T}_{\mathrm{w} 2} / \mathrm{D}, \mathrm{Q}_{\mathrm{f}}=\left(\mathrm{Q}_{\mathrm{fH}}{ }^{2}+\mathrm{Q}_{\mathrm{fv}}\right)^{1 / 2} &
\end{array}
$$

(2) 貫入条件と貫入形態の関係

羽一回転当たりの貫入形態例を図 6 に示す。ただし，a 図は，杭 一回転の変位を立体的に示したものであり，b図は杭面で平面展開 した図である。図中の $\mathrm{h}_{\mathrm{w}}$ は羽の螺旋ピッチ (羽ピッチ), $\mathrm{h}_{\mathrm{d}}$ は羽 が一回転によって進む距離（貫入ピッチ）である。 $\theta_{\mathrm{d}}$ は，上記平面 展開図に現れる螺旋状の掘削角度である。

図 7 に，回転条件 $1-\mathrm{b}$ 式を满足する場合の特徴的な貫入形態を 平面展開図によって示す。同図 $\mathrm{a}$ は貫入の無い空回り状態 $\left(\mathrm{P}_{0}<\mathrm{Q}\right.$ $\left.{ }_{f v}+R_{p}+P_{w}: h_{d}=0\right), b$ 図は貫入ピッチが羽ピッチ以下の半空回 り状態 $\left(\mathrm{P}_{0}=\mathrm{Q}_{\mathrm{fv}}+\mathrm{R}_{\mathrm{p}}+\mathrm{P}_{\mathrm{w}}: 0<\mathrm{h}_{\mathrm{d}}<\mathrm{h}_{\mathrm{w}}\right)$, c 図は貫入ピッチが 羽ピッチに一致する正規貫入状態 $\left(\mathrm{P}_{0}=\mathrm{Q}_{\mathrm{fv}}+\mathrm{R}_{\mathrm{p}}+\mathrm{P}_{\mathrm{w}}: \mathrm{h}_{\mathrm{d}}=\mathrm{h}_{\mathrm{w}}\right)$, d 図は, 貫入ピッチが羽ピッチよりも大きな過圧入状態（ $P_{0}=Q_{\mathrm{fv}}$ $+\mathrm{R}_{\mathrm{p}}+\mathrm{P}_{\mathrm{w}}: \mathrm{h}_{\mathrm{d}}>\mathrm{h}_{\mathrm{w}}$ ) である。なお, 本研究のような杭頭荷重 $\mathrm{P}_{0}$ $=0$ の貫入は $\mathbf{b}$ 図の貫入形態を示す。

(3) 羽近傍地盤に関する仮定

土が体積変化しないものと仮定すれば，掘削の形態は図 $6 \mathrm{~b}$ に示 したように空隙領域 $\triangle \mathbf{a} a{ }^{\prime} \mathbf{b} ’ か ゙$ 発生することになる。なお，同図の斜 線で示した $\mathrm{a}^{\prime}$ - $\mathrm{b}^{\prime}$ 上の土は，羽の前 1 回転によって掘削されたもの である。実際には，この空隙領域が大きい場合には，その一部は残 存するが，少ない場合には，地盤の膨張や周辺土の流れ込みにより
埋められる。しかし，何れの場合においても，羽下近傍地盤は応力 の開放によって拘束圧が低下することになる。上記空隙領域 $\triangle \mathbf{a} \mathbf{a}^{\prime} \mathbf{b}$ ' は，図示のように貫入ピッチ $h_{d}$ に依存するため，以下の仮定が成立 寸る。

仮定 $1 \cdot 1$ : 回転貫入時の羽下近傍地盤は拘束圧, 咧性および強度が 低下し，その度合いは貫入ピッチ $\mathrm{h}_{\mathrm{d}}$ に依存する。

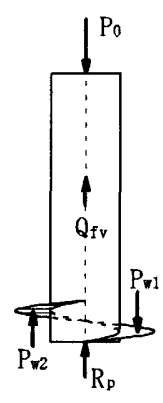

a. 鉛直荷重

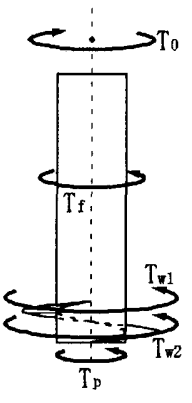

b. トルク

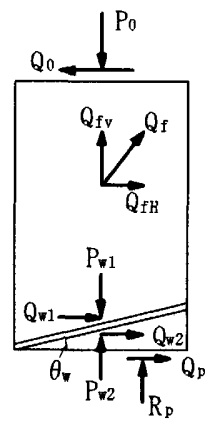

c. 鉛直荷重 - 換算水平力

图 5 荷重状態

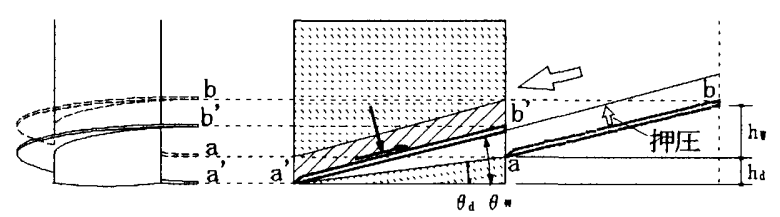

a. 貫入状況

b. 貫入状況の平面展開図 図 6 貫入状態例

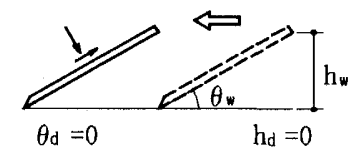

a. $h_{d}=0$ $\left(P_{0}<Q_{f v}+R_{p}+P_{w}\right)$

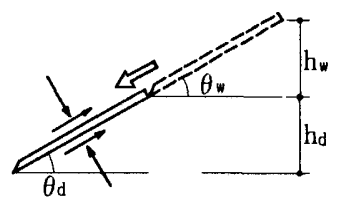

c. $\mathrm{h}_{\mathrm{d}}=\mathrm{h}_{\mathrm{w}}$ $\left(P_{0}=Q_{f v}+R_{p}+P_{w}\right)$

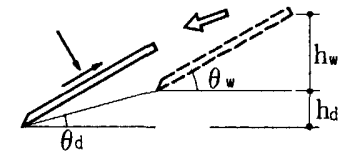

b. $0<\mathrm{h}_{\mathrm{d}}<\mathrm{h}_{\mathrm{w}}$ $\left(P_{0}=Q_{f v}+R_{p}+P_{w}\right)$

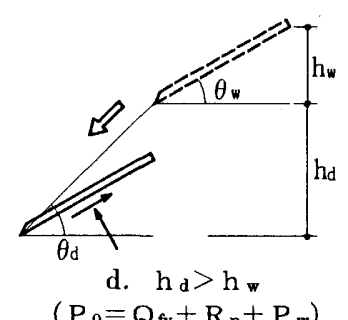

図 7 貫入の形態

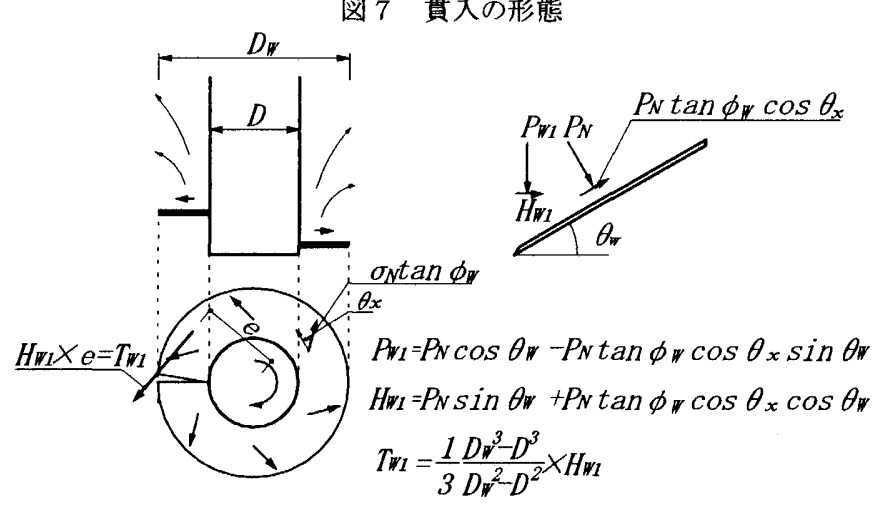

図8 羽上面の応力 
また，土の体積変化が無ければ，羽沈下体積と，羽上に移動する 羽下掘削土体積は同一であり，これらは互いに相殺されるが，図 7 に示したように，正規の羽ピッチ通りの貫入に対して，羽上地盤は 貫入ピッチ $\mathrm{h}_{\mathrm{d}}$ の距離を押圧されたことになる。また，杭体の貫入体 䅡に相応する分の側圧が増大する。したがって, 羽上地盤に関して 以下の仮定が成立するものとする。

仮定 1-2：回転貫入時の羽上近傍地盤は，拘束圧，晍性および強度

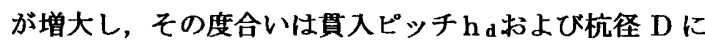
依存する。

回転貫入杭の羽ピッチ $\mathrm{h}_{\mathrm{w}}$ と回転のみによる貫入ピッチ $\mathrm{h}_{\mathrm{d}}$ に関 して, 以下の仮定が成立するものとする。なお，本仮定の妥当性は，

貫入試験結果の（3）の(1)よって示される。

仮定 $1 \cdot 3$ : 羽ピッチ $\mathrm{h}_{\mathrm{w}}$ が大きなものほど貫入ピッチ $\mathrm{h}_{\mathrm{d}}$ が增大する。

回転貫入中の羽上地盤は破壊状態にあり，羽の傾斜や回転運動に よる影響も受け, 羽上面の摩擦力は，図 8 に示すように角度を持っ て作用することが考えられ，以下の仮定が成立するものとする。 仮定 1 -4 : 羽上面に作用寸る回転抵抗摩擦力は，回転に抵抗するよ うに，羽外側に斜め方向に作用する。

\section{(4) 回転貫入に関する事項}

上記仮定 1 -1〜1-4により, 回転貫入時の羽近傍地盤に関して 以下の事項が成立する。

事項 1 - 1 : 回転貫入時の羽下近傍地盤の拘束圧, 㣚性および强度は 低下し，その低下の程度は羽ピッチ $\mathrm{h}$ wが大きなものほ ど大きくなる。

事項 1 - 2 : 回転貫入時の羽上近傍地盤の拘束圧, 用性および強度は 增大し，その增大の程度は羽ピッチ $\mathrm{h}$ 、が大きなものほ ど高くなる。

事項 $1 \cdot 3$ : 仮定 1-4 の羽上面に作用寸る回転抵抗摩擦力の角度を

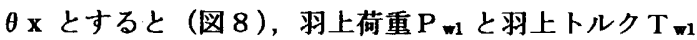
の間には，以下の関係式が成立する。

$$
\mathrm{T}_{\mathrm{wl}}=\frac{1}{3} \frac{\mathrm{D}_{\mathrm{w}}{ }^{3}-\mathrm{D}^{3}}{\mathrm{D}_{\mathrm{w}}{ }^{2}-\mathrm{D}^{2}} \frac{\tan \theta_{\mathrm{w}}+\tan \phi_{\mathrm{w}} \cos \theta x}{1-\tan \phi_{\mathrm{w}} \tan \theta \mathrm{w} \cos \theta x} \mathrm{P}_{\mathrm{w} 1}
$$

ただし，本式は図 8 中に示した力の関係から導かれる。なお， $\phi_{\mathrm{w}}$ は羽面と土の間の摩擦角である。

\section{(2) 貫入試験結果}

図 9 に，貫入ピッチ $\mathrm{h}_{\mathrm{d}}$ と貫入染さの関係，図 10 に鉛直変動土圧 分布の推移を示す。ただし，本図の a, b , c は，鉛直土圧の梁さ方向 の変動圧分布の推移を，貫入染さ $160,320,480 \mathrm{~mm}$ について示し たものである（土圧計 $\mathrm{V}_{1}, \mathrm{~V}_{2}, \mathrm{~V}_{3}, \mathrm{~V}_{6}, \mathrm{~V}_{9}, \mathrm{~V}_{13}, \mathrm{~V}_{16}$ )。なお，図が繁雑とな

るため，回転貫入杭については，羽ピッチ $\mathrm{P} 12 （ \mathrm{~h}_{\mathrm{w}}=12 \mathrm{~mm} ）$ および P36（ $\mathrm{h}_{\mathrm{w}}=36 \mathrm{~mm}$ ) のものだけを示す。同様に，図 11 に水平変動土 圧分布の推移を示寸 (土圧計 $\mathrm{H}_{1} \sim \mathrm{H}_{6}$ )。図 12〜図 18 に杭頭鉛直荷 重 $\mathrm{P}_{0}$, 先端部荷重 $\mathrm{P}_{\mathrm{w}}{ }^{*}$, 軸部先端荷重 $\mathrm{R}_{\mathrm{p}}$, 胴体部鉛直摩擦力 $\mathrm{Q}_{\mathrm{fv}}{ }^{*}$, 杭頭トルク $\mathrm{T}_{0}$, 胴体部摩擦トルク $\mathrm{T}_{\mathrm{f}}{ }^{*}$, 先端部トルク $\mathrm{T}_{\mathrm{w}}{ }^{*}$ の各荷重 と貫入深さとの関係を示す。

(3) 貫入試験結果の考察

(1) 貫入ピッチ $\mathrm{h}_{\mathrm{d}}$ : 図 9 の貫入ピ ッチ〜貫入深さ関係は，貫入初期 において，何れも小さな貫入ピッ チを呈しているが，貫入量が $150 \mathrm{~mm}$ 程度を越えると，貫入ピッ チは增大し，一定値に収束してい る。また,この収束値は, 羽ピッ チが大きなものほど大きな值を示 し, 上記仮定 1 - 3 が成立すること を立証している。

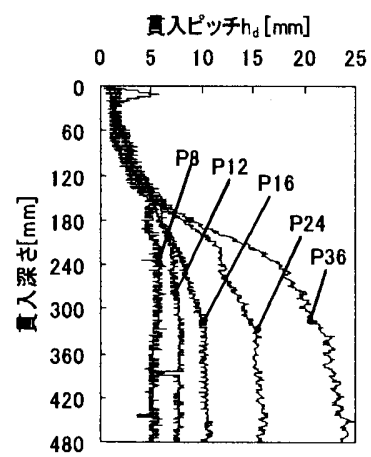

図 9 貫入ピッチ $h_{d}$

(2) 鉛直変動土圧分布の推移: ストレート杭の鉛直士圧変動は, 杭先 端下方で極大值が現れているのに対し，回転貫入杭では大きな変動 が認められなかった（図 10）。これは，ストレート杭において，杭 頭荷重 $\mathrm{P}_{0}$ は, 外的荷重として地中に伝達されるのに対し, 杭頭荷重 $\mathrm{P}_{0}=0$ とする回転貫入杭は, 羽上荷重 (推進力), 杭周面摩擦力お上 び軸部先端地盤反力が内的な釣合い関係にあるため，杭体から離れ た所への忘力伝達が少ないことに対応している。

(3) 水平変動土圧分布の推移: 回転貫入杭の水平土圧変動分布は, 羽 近傍で最大值を示し，杭体側方では圧入ストレート杭よりも大きな 土圧值を示している（図 11）。これは事項 1 - 2 に対応している。 (4) 杭頭荷重 $\mathrm{P}_{0}: \mathrm{P}_{0}$ は貫入打止め時までほぼゼロを示しており, 計 画通り, 羽荷重（羽推進力）のみによって貫入したことを示してい る(図 12)。

(5) 羽荷重 $\mathrm{P}_{\mathrm{w}}$, 胴体部周面摩擦力 $\mathrm{Qvv}^{*}$, 軸部先端荷重 $\mathrm{R}_{\mathrm{p}}$ : 図 20a は，貫入打止め時にお括利荷重 $\mathrm{P}_{\mathrm{w}}\left(=\mathrm{P}_{\mathrm{w}}{ }^{*}-\Delta \mathrm{Q}_{\mathrm{v}}\right)$ と压入ストレ 一ト杭の圧入荷重の比である。ただし， $\Delta \mathrm{Q}_{\mathrm{fv}}$ は，図 19 に示すよう に, 鉛直周面摩擦忘力度 $\tau \mathrm{rv}$ を直線分布と仮定し，杭周および胴体 部下端から羽取り付け上端までの積分值として求めた。図 $20 \mathrm{~b}$ は $\mathrm{Q}_{\mathrm{fv}}{ }^{*}$ に関する比，同 $\mathrm{c} に \mathrm{R}_{\mathrm{p}}$ に関する比を示した。貫入荷重比（図 $\mathrm{a}$ ） と軸部先端荷重比（図 c ）は，羽ピッチによる影響が認められなか ったが，周面摩擦力比（図 b ）は羽ピッチが大きなものほど大きな 值を示した。回転貫入杭の貫入荷重はストレート杭の $30 \%$ 程度，軸

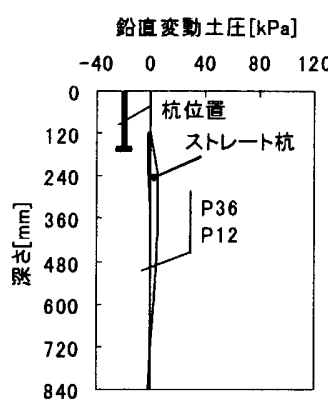
鉛但变動土压[kPa]

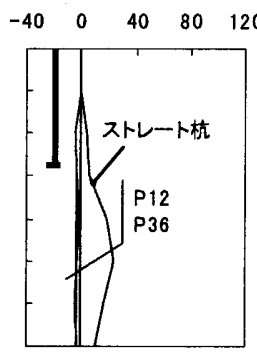

鉛正変㖶土圧 $[\mathrm{kPa}]$
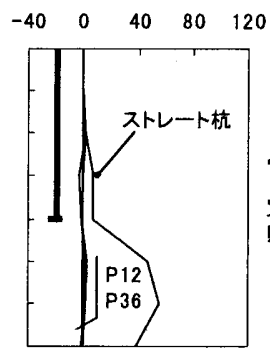

a. 貫入深さ $160 \mathrm{~mm} \quad$ b. 貫入深さ $320 \mathrm{~mm} \quad$ c. 貫入深さ $480 \mathrm{~mm}$ 図 10 鉛直変動土圧分布の推移（貫入試験時）
水平変動土压 $[\mathrm{kPa}]$

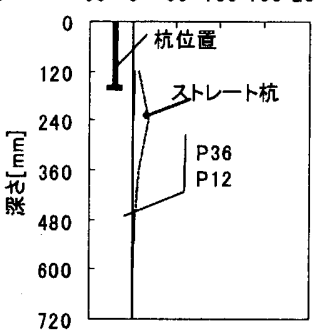

a. 貫入深さ $160 \mathrm{~mm}$
水平变動土圧[kPa]

水平变勤土压 $[\mathrm{kPa}]$

$\begin{array}{llllllllllll}-50 & 0 & 50 & 100 & 150 & 200 & -50 & 0 & 50 & 100 & 150 & 200\end{array}$

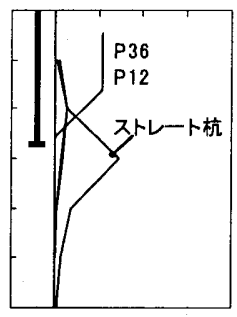

b. 貫入深さ $320 \mathrm{~mm}$ c. 貫入深さ $480 \mathrm{~mm}$ 図 11 水平変動土圧分布の推移（貫入試験時） 


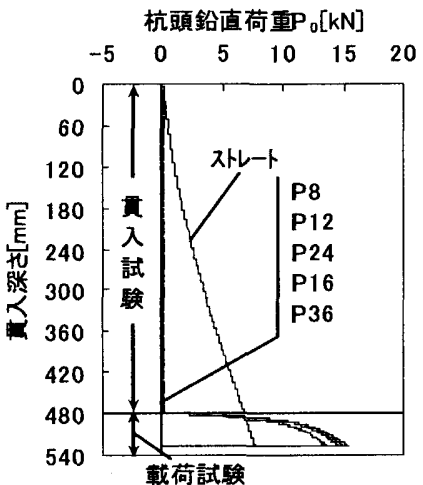

図 12 杭頭荷重 $P_{0}$

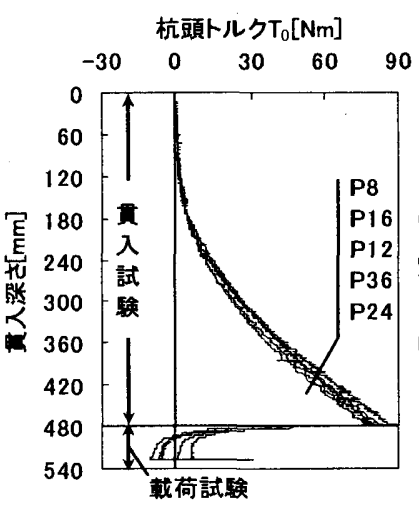

図 16 杭頭トルク $\mathrm{T}_{0}$

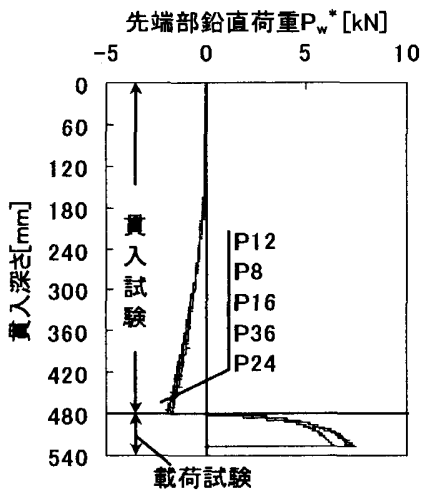

図 13 先端部鉛直荷重 $\mathrm{P}_{\mathrm{w}}$ *

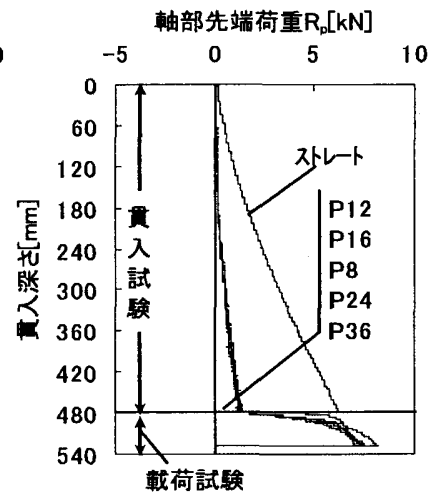

図 14 軸部先端荷重 $R_{p}$

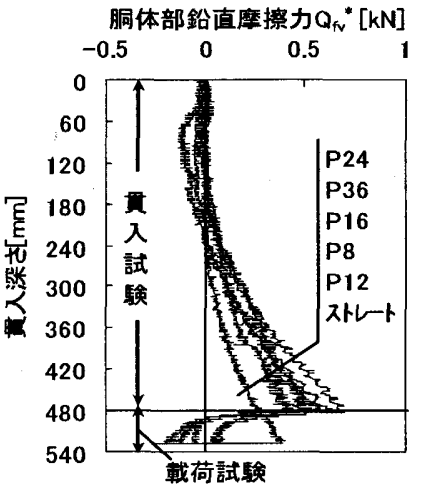

図 15 胴体部鉛直摩擦力 $\mathrm{Qfv}^{*}$

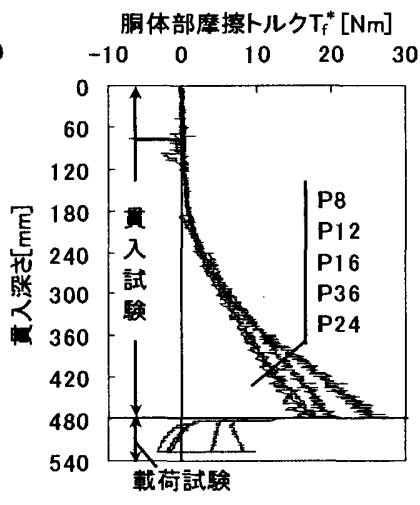

図 17 胴体部摩擦トルク $\mathrm{T}_{\mathrm{f}}^{*}$

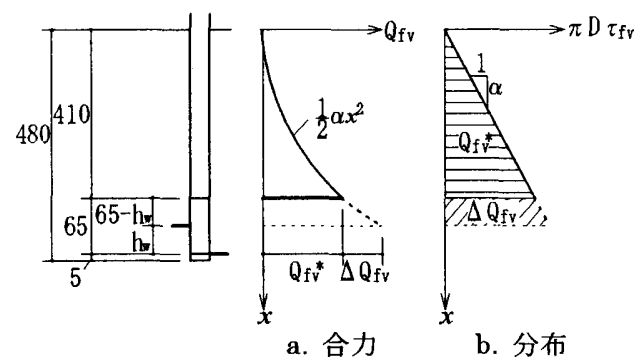

図 19 周面摩擦力の補正方法

部先端荷重は $20 \%$ 程度であり，事項 1 -1 に対応した。

(6) 杭頭トルク $\mathrm{T}_{0}$ :, 貫入打止め時の $\mathrm{T}_{0}$ は図 $21 \mathrm{a}$ に示したように, 羽ピッチが大きくなると減少傾向にある。なお， 1 - b 式に示した ように，その力学的性状は周面摩擦トルク $\mathrm{T}_{\mathrm{f}}$, 軸部先端摩擦トル ク $\mathrm{T}_{\mathrm{p}}$ および羽トルク $\mathrm{T}_{\mathrm{w}}$ に依存する。また, $\mathrm{T}_{\mathrm{f}}$ は胴体部摩擦トルク $\mathrm{T}_{\mathrm{f}}{ }^{*}$ と先端部摩擦トルク $\Delta \mathrm{T}_{\mathrm{f}}$ との和 $\left(\mathrm{T}_{\mathrm{f}}=\mathrm{T}_{\mathrm{f}}{ }^{*}+\Delta \mathrm{T}_{\mathrm{f}}\right), \mathrm{T}_{\mathrm{w}}$ は先端 部トルク $\mathrm{T}_{\mathrm{w}}{ }^{*}$ から，先端部周面摩擦トルク $\Delta \mathrm{T}_{\mathrm{f}}$ と軸部先端トルク $\mathrm{T}_{\mathrm{p}}$ を差し引いた值である $\left(\mathrm{T}_{\mathrm{w}}=\mathrm{T}_{\mathrm{w}}{ }^{*}-\Delta \mathrm{T}_{\mathrm{f}}-\mathrm{T}_{\mathrm{p}}\right)$ 。ここに, $\mathrm{T}_{\mathrm{f}}{ }^{*} お$ よび $\mathrm{T}_{\mathrm{w}}{ }^{*}$ の值は害験結果として図 17 および図 18 に示しており， $\mathrm{T}_{\mathrm{f}}$ は, 水平摩擦応力度 $\tau_{\mathrm{fH}}$ が染さ方向に対して直線分布と仮定する ことによって，上記(5の $\Delta \mathrm{Q}_{\mathrm{fv}}$ を算出した方法によって求められる。 また, $\mathrm{T}_{\mathrm{P}}$ は, 軸部先端面の接地圧が等分布であり，摩擦方向の角 度は図 $80 \theta x$ と同一とし, $\theta x=\theta{ }_{\mathrm{w}}+\phi_{\mathrm{w}}$ と仮定すると, 次式 $3 に$ よって求められる。なお, 式中の $\phi_{w}$ は軸部先端面と地盤との摩擦 角である。

$$
\mathrm{T}_{\mathrm{P}}=\mathrm{D} \mathrm{R}_{\mathrm{p}} \tan \phi_{\mathrm{w}} \cos \left(\theta_{\mathrm{w}}+\phi_{\mathrm{w}}\right) / 3
$$

(7) 胴体周面摩擦トルク $\mathrm{T}_{\mathrm{f}}{ }^{*}$ : 図 17 に示したように $\mathrm{T}_{\mathrm{f}}{ }^{*}$ は, 羽ピッ チが小さいものほど，より大きな値を示す傾向にあることが認めら

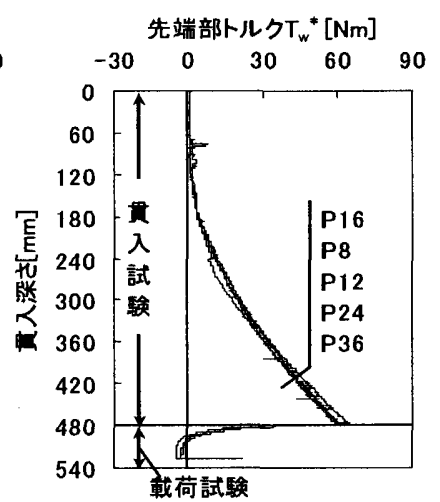

図 18 先端部トルク $\mathrm{T}_{\mathrm{w}}{ }^{*}$

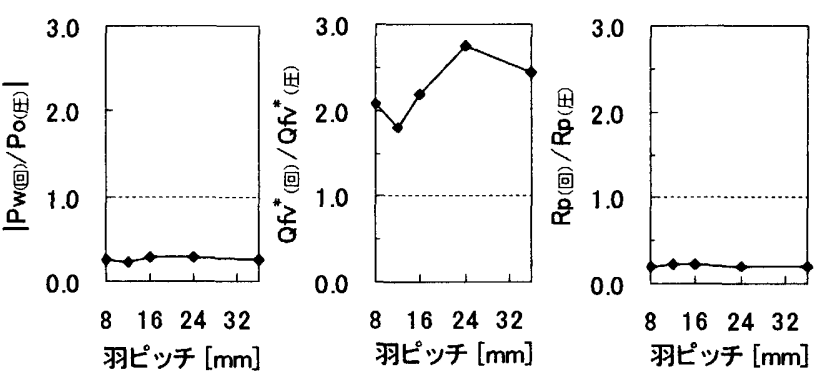

a. 貫入荷重比 b. 鉛直摩擦力比 c. 軸部先端荷重比 図 20 圧入ストレート杭との比較（貫入打止め時）

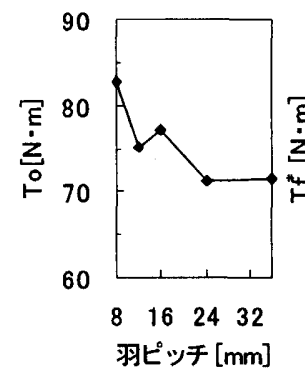

a. 杭頭トルク

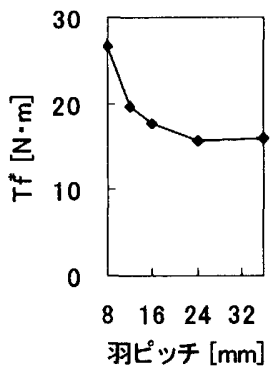

b. 摩擦トルク

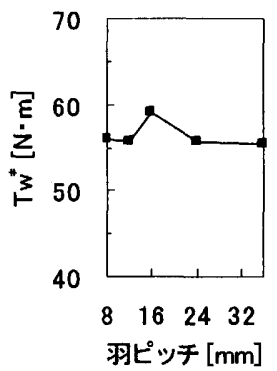

c. 先端部トルク
図 21 各トルク值 (貫入打止め時)

\section{れる。これについては以下に考察する。}

図 22 に, 胴体部鉛直摩擦力 $\mathrm{Q}_{\mathrm{fv}}{ }^{*}$ （図 15）と胴体部の換算水平摩 擦力 $\mathrm{Q}_{\mathrm{fH}}{ }^{*}\left(=2 \mathrm{~T}_{\mathrm{f}}{ }^{*} \mathrm{D}\right)$ の合力 $\mathrm{Q}_{\mathrm{f}}{ }^{*}$ 示す。何れも，ストレート杭の Qfvよりも大きく, 事項 $1-2$ に対応している。図 23 は, 横軸に水 平摩擦力, 縦軸に鉛直摩擦力とした座標上に, 貫入打止め時の胴体 部の摩擦力 $\mathrm{Q}_{\mathrm{H}}{ }^{*}$ と $\mathrm{Q}_{\mathrm{fv}}{ }^{*}$ をプロットし, $\mathrm{Q}_{\mathrm{f}}{ }^{*}$ の大きおおよ゙その傾き 


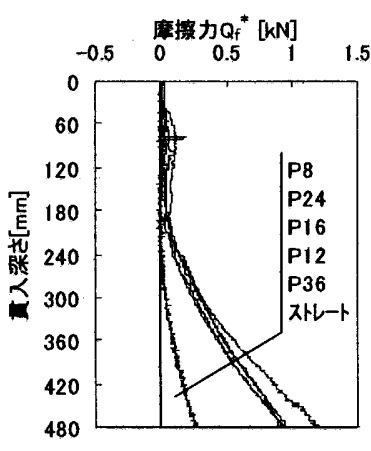

図 22 胴体部摩擦力 $\mathrm{Qi}^{*}$

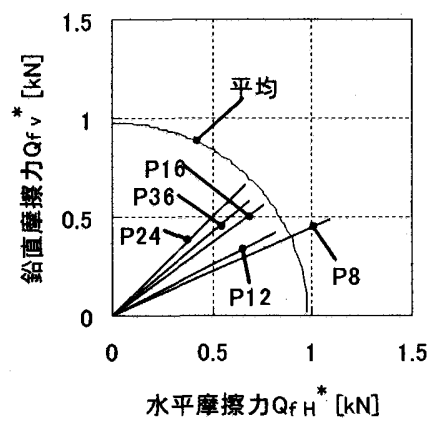

図 $23 \mathrm{Q}_{\mathrm{fv}}{ }^{*} \sim \mathrm{Q}_{\mathrm{fH}}$ 関係

$\theta=\tan ^{-1}\left(\mathrm{Q}_{\mathrm{HH}}{ }^{*} / \mathrm{Q}_{\mathrm{fV}}{ }^{*}\right)$ を示したものである。これらは, 羽ピッチ $\mathrm{P} 8$

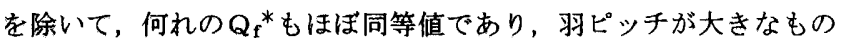
ほど傾斜角 $\theta$ が大きくなる傾向を示し， $\mathrm{Q}_{\mathrm{fv}}{ }^{*}=\mathrm{Q}_{\mathrm{f}}{ }^{*} \sin \theta, \mathrm{Q}_{\mathrm{H}}{ }^{*}=$ $\mathrm{Q}_{\mathrm{f}}{ }^{*} \cos \theta$ の関係にある。これらの関係は, 羽ピッチが小さな方が大 きなものよりも，鉛直成分 $\mathrm{Q}_{\mathrm{fv}}{ }^{*}$ が小さくなり，逆に水平成分 $\mathrm{Q}_{\mathrm{fH}}{ }^{*}$ は大きくなることを意味する。したがって，水平成分 $\mathrm{Q}_{\mathrm{M}}{ }^{*}$ と依存関 係にある $\mathrm{T}_{\mathrm{f}}{ }^{*}\left(=2 \mathrm{Q}_{\mathrm{fH}}{ }^{*} / \mathrm{D}\right)$ も，羽ピッチの小さな方がより大きな值を 示し， $\mathrm{T}_{\mathrm{f}}{ }^{*}$ の実験結果（図 17）に対応している。なお，合力 $\mathrm{Q}_{\mathrm{f}}{ }^{*}$ に 対する羽ピッチの影響は認められなかった。

(8) 羽トルク $T_{w}$ および事項 $1-3$ 式の検証

回転貫入時において, 羽下に空隙が発生し得ることから, 羽下荷 重 $\mathrm{P}_{\mathrm{w} 2}=\mathrm{T}_{\mathrm{w} 2}=0$ と仮定する。したがって, 羽上荷重 $\mathrm{P}_{\mathrm{w}_{1}}$ は(5)によっ て得られた羽荷重 $P_{w}$ に一致する（ $\left.P_{w_{1}}=P_{w}\right)$ 。また, 軸部先端トル ク $\mathrm{T}_{\mathrm{p}}$ は，3式によって算出され，羽トルクは $\mathrm{T}_{\mathrm{w}}=\mathrm{T}_{\mathrm{w}}{ }^{*}-\Delta \mathrm{T}_{\mathrm{f}}-\mathrm{T}_{\mathrm{p}}$ によって求められる。図 24 の太線は羽面の摩擦角度 $\phi_{w}=30^{\circ}$ と仮 定し, 各羽ピッチに対して求めたものである。これは羽ピッチが大 きくなると $\mathrm{T}_{\mathrm{w}}$ は増大傾向にあり, 事項 $1-2$ に対応している。また, 上記羽荷重 $\mathrm{P}_{\mathrm{w} 1}$ を事項 $1-3$ 式に適用すると, 理論解 $\mathrm{T}_{\mathrm{w}}$ (細線) が 実験值にほぼ対応するものとして求められる（図 24）。ただし，理 論解は, 羽掘削刃先および羽厚周面の応力を無視しており，また， 羽および軸部先端面の摩擦の発生角度は試算によって与えたもので あるため，改良の余地を多く残すものである。

\section{4. 載荷試験結果と支持力発現のメカニズム}

（1）支持力発現のメカニズム

(1) 載荷進行時の仮定

載荷時の羽の沈下と羽近傍地盤に関して，以下の仮定が成立する ものとする。

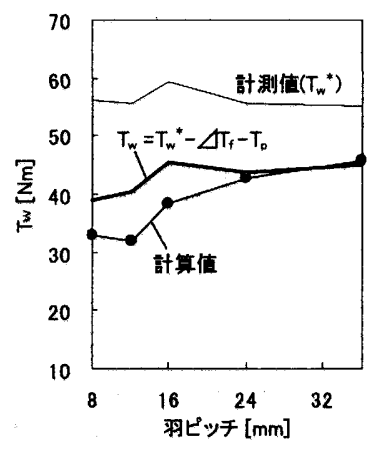

図 24 事項 $1 \cdot 3$ 式の検証
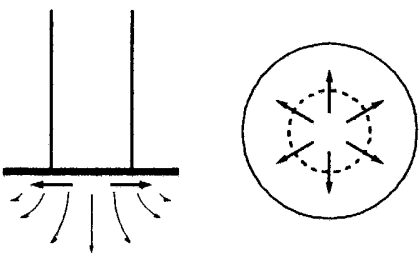

a. 平羽
仮定 $2 \cdot 1$ : 載荷による羽の沈下は, 羽下近傍地盤を押圧し, 羽下近 傍地盤の拘束圧，喇性および強度をより增大させる。

仮定 2-2：載荷による羽の沈下は, 羽上近傍地盤の応力を開放し, 羽上近傍地盤の拘束圧, 甽性および強度をより低下させ る。

(2) 極限荷重時の仮定

仮定 $2 \cdot 3$ : 極限荷重時の羽下面の摩擦力の向きは羽角度 $\theta_{\text {w }}$ に依存 し，羽下からから見た羽下面において，杭中心を通る線 と時計回りに $\theta_{\mathrm{w}}$ の角度をなす（図25）。

事項 $2 \cdot 3$ : 極限荷重時の羽下荷重 $P_{w_{2}}$ による羽下トルク $\mathrm{T}_{w_{2}}$ は以 下の関係にある。

$$
\mathrm{T}_{\mathrm{w} 2}=\frac{1}{3} \frac{\mathrm{D}_{\mathrm{w}}{ }^{3}-\mathrm{D}^{3}}{\mathrm{D}_{\mathrm{w}}{ }^{2}-\mathrm{D}^{2}} \frac{1-\tan \phi_{\mathrm{w}} \cos \theta_{\mathrm{w}}}{\cot \theta_{\mathrm{w}}+\tan \phi_{\mathrm{w}} \sin \theta_{\mathrm{w}}} \mathrm{P}_{\mathrm{w} 2}
$$

（解説）図 25 a に示すように，羽が傾斜の無い平羽である場合，鉛 直荷重が作用すると，羽下面摩擦力の作用方向は，円中心から放射 状に外に向から。螺旋羽では，同図bに示すように，中心線を通る 線に対してある角度 $\theta$ を持ち，その角度は，羽ピッチが大きなもの ほど大きくなることは容易に推測される。同図 c は, 羽态力を杭周 面の平面展開図上に示したものである。なお，上記仮定 $2 \cdot 3$ はこの 摩擦の傾きを羽角度 $\theta_{\mathbf{w}}$ と仮定するものである。事項 $2-3$ 式は，同 図 c 中に示す力の関倸から導かれる。

\section{（2）載荷試験結果}

図 26 に鉛直変動土圧分布の推移，図 27 に水平土圧の染さ方向の 変動圧分布の推移を示す（載荷開始時，沈下 $0.1 \mathrm{D}$ 時，1D 時）。図 28～図 34 に，杭頭鉛直荷重 $\mathrm{P}_{0}$, 先端部荷重 $\mathrm{P}_{w}{ }^{*}$ ，軸部先端荷重 $\mathrm{R}_{\mathrm{p}}$, 胴体部鉛直摩擦力 $\mathrm{Q}_{\mathrm{fv}}{ }^{*}$ ，杭頭トルク $\mathrm{T}_{0}$, 胴体部摩擦卜ルク $\mathrm{T}_{\mathrm{f}}{ }^{*}$, 先端部トルク $\mathrm{T}_{\mathrm{w}}{ }^{*}$ の各荷重と沈下との関係を示す。

（3）載荷試験結果の考察

(1) 鉛直変動土圧分布の推移: 鉛直変動土圧分布の推移は羽下方で最 大となる增圧分布を示し, 最終荷重時において, ストレート杭より も大きな增圧値を示している（図 26）。羽上の変動土圧は低下傾向 にあり, 前者は仮定 $2-1$ に, 後者は仮定 $2-2$ に対応している。 (2) 水平変動土圧分布の推移: 杭側方の変動土圧は减圧傾向を示し, 杭先端以染の変動圧分布の最大值は, 沈下が進行するとストレート 杭のものよりも大きくなっている（図 27）。なお，この杭側方の土

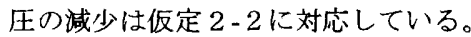

(3) 杭頭荷重 $P_{0}$, 胴体部周面摩擦力 $Q_{\mathrm{fv}}{ }^{*}$, 軸部先端荷重 $\mathrm{R}_{\mathrm{p}}$ : 図 36a に，杭頭荷重 $\mathrm{P}_{0} \sim$ 沈下曲線（図 28）における 0.05D 時の割線係数, 沈下 $0.1 \mathrm{D}$ および沈下 $1 \mathrm{D}$ 時の杭頭荷重とストレート杭の杭頭荷重 との比を示した。同様に, 図 36b には胴体部周面摩擦力 $\mathrm{Q}_{\mathrm{fv}}{ }^{*} \sim$ 沈下 曲線（図 31）における関係，図 $36 \mathrm{c}$ に軸部先端荷重 $R_{\mathrm{p}} \sim$ 沈下曲線
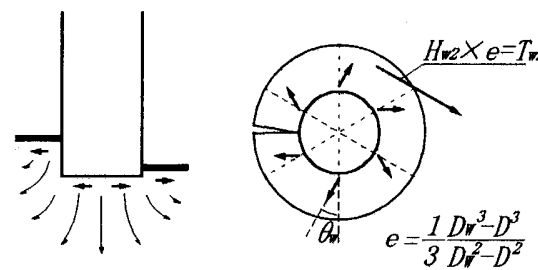

b. 螺旋羽

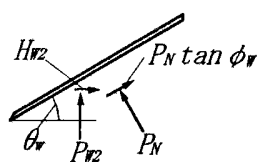

c. 平面展開図
図 25 羽下面に作用寸る忘力 


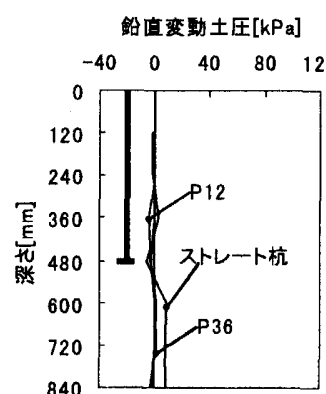

a. 載荷開始時
魵直変轨土压[kPa]

鉛匽变野土圧 $[\mathrm{kPa}]$

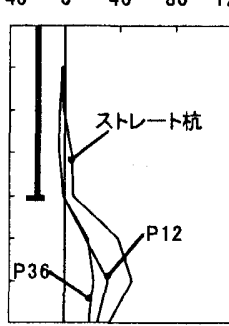

b. $4.8 \mathrm{~mm}$ (0.1D 時)

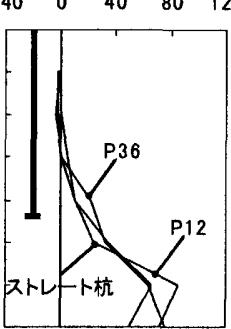

c. $48 \mathrm{~mm}$ ( $1 \mathrm{D}$ 時)

図 26 鉛直変動土圧分布の推移（載荷試験時）
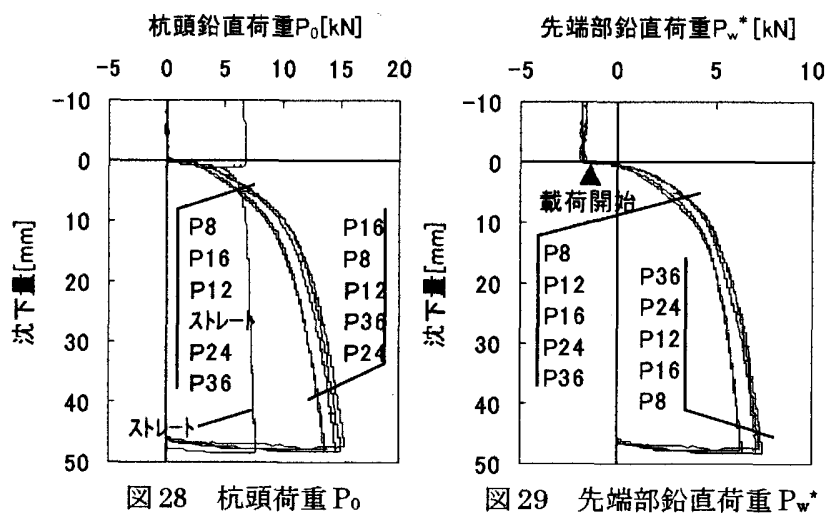

杭頭トルク $\mathrm{r}_{0}[\mathrm{Nm}]$

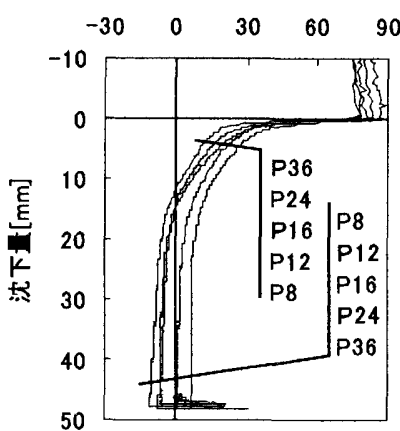

図 32 杭頭トルク $\mathrm{T}_{0}$

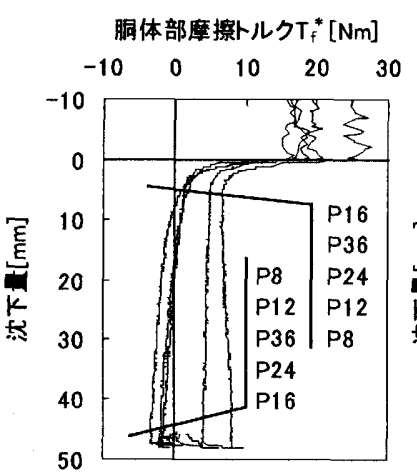

図 33 胴体部摩擦トルク $\mathrm{T}_{\mathrm{f}}$

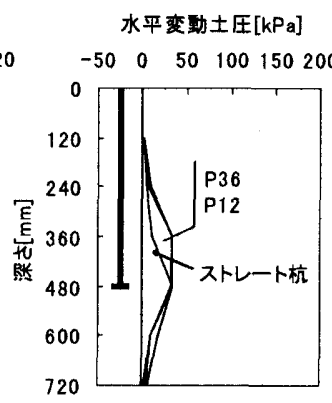

a. 載荷開始時 $\quad$ b. $4.8 \mathrm{~mm}(0.1 \mathrm{D}$ 時)

載荷開始時 $\quad$ b. $4.8 \mathrm{~mm}(0.1 \mathrm{D}$ 時 $)$ b. $4.8 \mathrm{~mm}(0.1 \mathrm{D}$ 時 $)$

水平変勤土压[kPa]

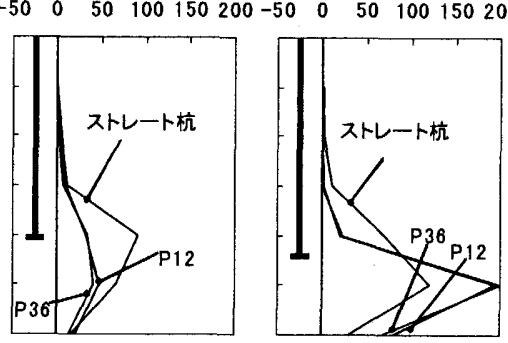

c. $48 \mathrm{~mm}$ ( $1 \mathrm{D}$ 時) c. $48 \mathrm{~m}$ (荷試験時)
軸部先端荷重 $\mathrm{R}_{0}[\mathrm{kN}]$

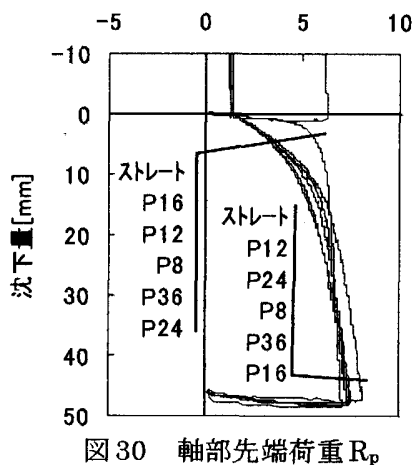

先端部卜ルク $\mathrm{T}_{w}{ }^{*}[\mathrm{Nm}]$

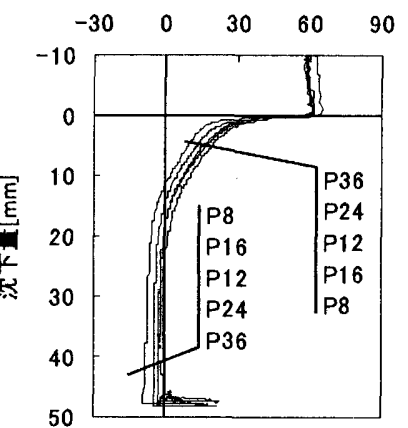

図 34 先端部トルク $\mathrm{Tw}^{*}$
漏体部鉛直摩擦力 $Q_{\mathrm{fv}}{ }^{*}[\mathrm{kN}]$

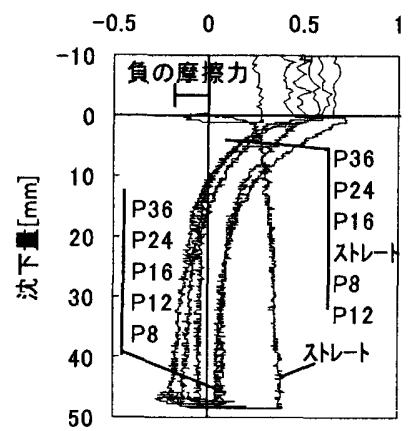

図 31 胴体部鉛直摩擦力 $\mathrm{Qfv}^{*}$ 羽部軸部荷重度比

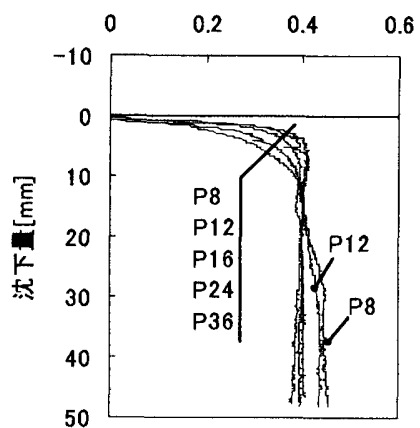

図 35 羽部軸部荷重度比
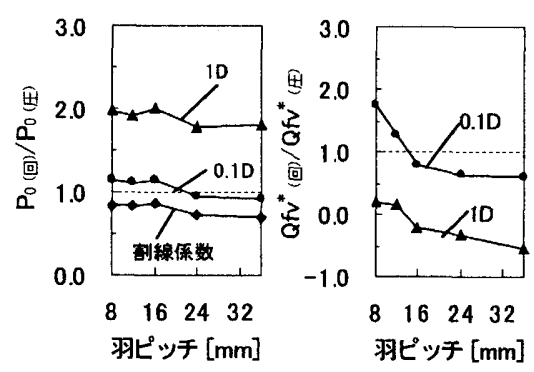

a. 貫入荷重比

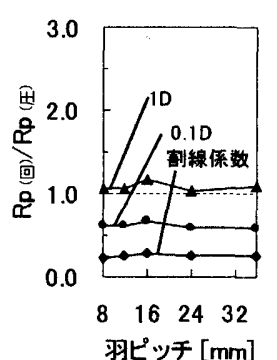

c. 軸部先端荷重比

図 36 圧入ストレート杭との比較（載荷試験時）

（図 30）における関係を示した。軸部先端荷重 $\mathrm{R}_{\mathrm{p}}$ は, 羽ピッチに よる影響が認められなかったが, 杭頭荷重 $\mathrm{P}_{0}$ と周面摩擦力 $\mathrm{Q}_{\mathrm{fv}}{ }^{*}$ に 関しては，羽ピッチが大きくなると低下傾向を示している。特に， $\mathrm{R}_{\mathrm{p}}$ は, ストレート杭との比較において, 初期荷重が小さく（低い割

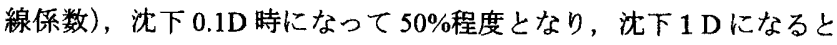
若千大きくなっている。なお, 回転貫入杭の初期荷重の低さは, 貫 入時に生じた羽下地盤の緩みが残存しているためであり，沈下 $1 \mathrm{D}$ 時の荷重の增大は, 羽の沈下による先端地盤の押さえ効果によるも
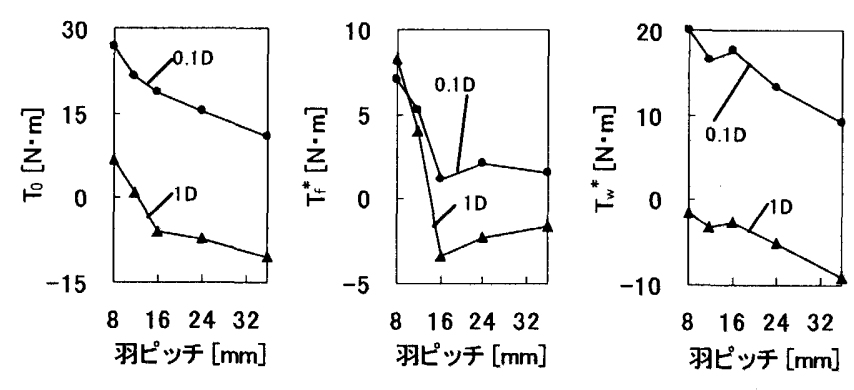

a. 杭頭トルク

b. 摩擦トルク

図 37 各トルク值（載荷試験時）

のと推察される。また，周面摩擦力 $\mathrm{Q}_{\mathrm{fv}}{ }^{*}$ は, 沈下 $1 \mathrm{D}$ 時において P8 と P12 を除き, 負の摩擦力を示している。この負の周面摩擦力は, 沈下する羽上面に, 羽上土砂が落ち込んだことによって生じたもの と推察される。なお, 沈下 $0.1 \mathrm{D}$ 時点では負の摩擦に至ってはいない が, $\mathrm{Q}_{\mathrm{fv}}{ }^{*} \sim$ 沈下関俰（図 31）は, 載荷の進行と共に, 胴体部周面摩 擦力が大きく低下することを示唆している。

注）図 31 に見られるストレート杭における載荷開始時の負の周面 摩擦力の発生は, 以下によって説明される。貫入時の杭頭荷重 $\mathrm{P}_{0}$, 
杭先端地盤反力 $\mathrm{R}_{\mathrm{P}}$ と周面摩擦力 $\mathrm{Q}_{\mathrm{fv}}$ は $\mathrm{P}_{0}=\mathrm{R}_{\mathrm{P}}+\mathrm{Q}_{\mathrm{fv}}$ の関係にあり， 杭頭荷重 $P_{0}=0$ に除荷すると, $R_{P}+Q_{f v}=0$, 即ち, $Q_{f v}=-R_{P}\left(R_{P}\right.$ >0）となり, 圧入ストレート杭の鉛直摩擦力〜沈下関係は, 負の摩 擦力から始まることになる。

(4) 杭頭トルク $\mathrm{T}_{0}$, 胴体部周面摩擦トルク $\mathrm{T}_{\mathrm{f}}{ }^{*}$, 先端部トルク $\mathrm{T}_{\mathrm{w}}{ }^{*}$ : $\mathrm{T}_{0}, \mathrm{~T}_{\mathrm{f}}{ }^{*}, \mathrm{~T}_{\mathrm{w}}{ }^{*}$ の各トルク〜沈下曲線（図 32〜34）は, 貫入時の卜 ルクが残留しているため，正のトルクから始まり，載荷が進行する と，急激な低下傾向を示している。それらの低下傾向は羽ピッチが 大きなものほど大きくなっている。図 37a は沈下 0.1Dおよび 1D 時 の $\mathrm{T}_{0}$ と羽ピッチの関倸, 図 $37 \mathrm{~b}$ は $\mathrm{T}_{\mathrm{f}}{ }^{*}$ の関倸, 図 $37 \mathrm{c}$ は $\mathrm{T}_{\mathrm{w}}{ }^{*}$ の関倸 を示したものである。これらは, 羽ピッチが大きなものほど大きく 低下している。

(5) 事項 $2 \cdot 3$ 式の検証: 図 38 は 極限荷重時の実験結果から求め た羽トルクと事項 2 - 3 式によ る羽トルクを各羽ピッチに対し て示したものである。なお，実 験による $\mathrm{T}_{\mathrm{w}}$ は先端部トルク $\mathrm{T}_{\mathrm{w}}{ }^{*}$ から軸部先端卜ルク $T_{p}$ と先端 部周面摩擦トルク $\Delta \mathrm{T}_{\mathrm{f}}$ を差し引 いた值であるが,載荷時には周 面摩擦力が急减することから $\mathrm{T}_{\mathrm{f}}$ を無視し, $\mathrm{T}_{\mathrm{w}}=\mathrm{T}_{\mathrm{w}}{ }^{*}-\mathrm{T}_{\mathrm{p}}$ とし

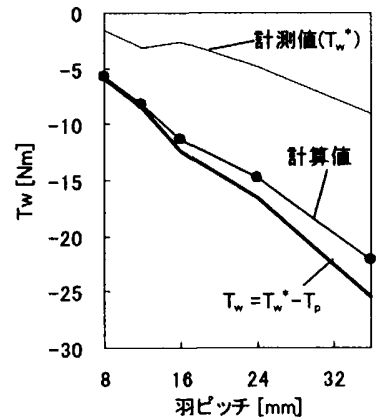

図 38 事項 $2 \cdot 3$ 式の検証
て計算した。ここに， $T_{p}$ は軸部先端面の接地圧が等分布と仮定し， 軸部先端面に作用する摩擦力の方向が回転に抵抗する斜め角度を持 ち，その角度を羽角度 $\theta_{\mathrm{w}}$ と仮定することによって得た下式（5） から計算される。ただし, 軸部先端面と地盤との摩擦角は $\phi_{\mathrm{w}}=30^{\circ}$ とした。

$$
\mathrm{T}_{\mathrm{P}}=\mathrm{D} \mathrm{R}_{\mathrm{P}} \tan \phi_{\mathrm{w}} \sin \theta_{\mathrm{w}} / 3
$$

また，事項 $2-3$ 式による計算値は，羽上土圧が低下しているため， 羽上荷重 $\mathrm{P}_{\mathrm{w} 1}$ および先端部鉛直摩擦力 $\Delta \mathrm{Q}_{\mathrm{fv}}$ を無視し, $\mathrm{P}_{\mathrm{w} 2}=\mathrm{P}_{\mathrm{w}}{ }^{*}$ （図 29）として求めたものである。

これらの結果は良く一致しており，事項 $2-3$ 式は，ほぼ妥当であ ると判断される。

(6) 羽部軸部荷重度比: 載荷試験時における羽部軸部荷重度比（軸部 先端荷重度 $[\mathrm{Pa}]$ に対する羽荷重度 $[\mathrm{Pa}$ ]の割合）と沈下の関係を図 35 に示す。これらの曲線の初期勾配は，羽ピッチが大きなものほど低 くなっており，沈下 0.1D (4.8mm) 時において，羽ピッチが小さな ものから順に $0.390 .370 .33 \quad 0.30$ の比率となった。また，沈下量が $10 \mathrm{~mm}$ 程度（軸径の 0.2 倍）となると，P8 および P12 を除いてほぼ 0.4 に収束し，一定比で推移している。なお，羽軸部径比が大きくな ると，上記収束值も大きくなることを確認している7）。

\section{5. 結 論}

乾燥砂地盤における回転のみによって貫入させた回転貫入模型杭 に関して，以下の知見が得られた。

（1）回転貫入時

(1) 回転貫入時の羽下近傍地盤は，拘束圧，剛性および強度が低下し， 压入ストレート杭の貫入力よりも低い羽推進力で貫入する。 (2) 回転貫入時の羽上近傍地盤の拘束圧，㓮性および強度は増大し，
圧入ストレート杭よりもより大きな摩擦力を発現する。

(3) 羽ピッチが大きなものほど鉛直周面摩擦力は大きくなるが, 周面 摩擦トルクは，羽ピッチが小さなものよりも小さくなる。

(4) 回転貫入時の羽荷重と羽トルクに関する関係式を導き, 本実験結 果にほぼ対応することを確認した。

（2）鉛直載荷時

(1) 載荷初期の杭頭荷重は, 回転貫入によって杭先端地盤が緩められ ており，圧入ストレート杭よりも低く現れる。この傾向は, 羽ピッ チが大きいものほど強く現れ，初期剛性はより低下する。

(2) 極限時の軸部先端荷重は, 羽の押さえ効果によって増大し，圧入 ストレート杭のものよりも大きくなる。

(3) 載荷による羽の沈下に伴って, 羽上荷重, 羽上トルクおよび周面 摩擦力は減少する。この減少傾向は, 羽ピッチが大きいものほど強 く現れる。

(4) 載荷極限時の羽下荷重と羽下トルクに関する理論式を提案し, 本 実験結果に良く対応することを確認した。

(3) 今後の課題

本研究の成果は，直接的に実大杭に対応するものとは考えてはい ないが，適切な力学モデルは模型杭および実物杭を問わず適合する ものと考えている。今後の課題は，貫入時および載荷時における力 学モデルを構築し，より精度の高い模型実験を行うことによって検 証することを考えている。

謝辞 本研究を遂行するにあたり新日本製鐵(株)佐伯英一郎氏， 日本大学理工学部海洋建築工学科大学院修了生 橋本吉朗氏, 長澤 䣓氏，柏木将臣氏，ならびに同学科卒業研究生諸氏の多大なる協力 を得ました。末筆ながらここに感謝の意を表します。

\section{[参考文献]}

1) Jacobu and Davis: Foundations of Bridges and Buildings., 1914 2)板谷國夫，吉田勝之：小規模建築用羽根付き小径鋒管杭の施工と鉛直載荷試験，日本 建策学会大会学術硾演梗概集，pp. 1265-1266, 1986.8

3)国付田誡，佐藤秀人，田村昌仁，橋本吉朗，長澤删：回転貫入杭に関する研究，1.

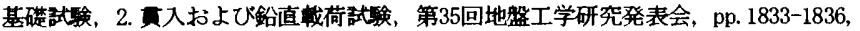
2000.7

4）田村昌仁，国府田誠，高野公寿，廣瀬智治：建築における最新の鍮管杭基礎の設計と 施工，基砒工 Vol. $28 ，$ pp. $18-24 ， 2000.12$ 5) 国府田誠，佐藤秀人，田村昌仁，長濢删 : 回転貫入杭の貫入および支持力機構に関卞 る基㗪的研究，その1. 貫入圾験および載荷試呀，その2. 貫入機構および支持力機構，第 36回地整工学研究発表会, pp. 1625-1628，2001.6

6)柏木将臣，国府田誠，佐藤秀人，田村昌仁，佐伯英一郎 他 : 回転貫入杭の貫入性状 および支持力性状に関する研究一模型杭による貫入試験と載荷試験一, 日本建勧学会大 会学術講演梗概集 棈造 I, pp. 611-612, 2001.9

7) 国府田誠，佐藤秀人，永田誠，平田尚，田村昌仁，刑部徹 : 羽径に着目した回転貫入 杭の模型実験, その1. 貫入試験, その2. 載荷試験, 第38回地盤工学研究発表会, pp. 1481-1484, 2003. 7

8)国付田誠，佐藤秀人，开部徹，氷田誠 他: 羽ピッチに着目した回転貫入杭の模型実 験, 1. 貫入試験，2. 載荷試験，第39回地盤工学研究発表会, pp. 1537-1540,2004.7 9)国司基，国府田誠，佐藤秀人，水田誠 他：土圧に着目した回転貫入杭の貫入性状に 関する模型実験，第40回地整工学研究発表会，pp. 1579-1580, 2005.7 10)刑部徹, 国府田誠，佐藤秀人，永田誠 他：土王に着目した回転貫入杭の支持力性 状に関する模型実験，第40回地盤工学研究発表会, pp. 1579-1580, 2005.7 11)佐伯英一郎，大木仁：回転圧入鋼管杭几関する研究一施工試験及乙載荷武験結果と 貫入のメカニズム一，構造工学論文集 Vol. 45B, pp.453-462，1999. 3

12）土屋勉，大杉富美一，稲国芳，吉田勝之 : 翼付き鋼管杭の軸力測定法，土と基礎 Vol. 48 , No. 8, pp. 17-19, 2000. 8

13) 土屋勉:最近の埋込み杭施工法の動向と今後の展望, 基礎工 Vol. 31, №. 9, pp. 11-15, 2003.9

14）大杉富美，土屋勉，島田正夫，吉田勝之 : 大型加圧土槽を利用した回転貫入模型 杭の貫入試験，日本建築学会構造系論文集 Vol.591，pp.69-75, 2005.5 